Darja Mertelj

UDK: 811.131.1'243:37.091.26

Filozofska fakulteta Univerze v Ljubljani

darja.mertelj@guest.arnes.si

\title{
TESTIRANJE RECEPTIVNIH IN JEZIKOVNE ZMOŽNOSTI V ITALIJANŠČINI MED ŠTUDENTI ITALIJANISTIKE
}

\section{UVOD}

Med pomembna vprašanja $\mathrm{v}$ zvezi s poučevanjem tujega jezika sodijo tudi merjenje jezikovnih zmožnosti, mednarodna primerjava in uravnavanje rezultatov, predvsem na evropski ravni, saj tudi tovrstno preučevanje poučevanja in učenja tujih jezikov lahko pripomore $\mathrm{k}$ uresničevanju evropske jezikovne politike v stvarnosti na vseh ravneh izobraževanja, tudi na fakultetni.

Pričujoči prispevek sodi na področje poučevanja italijanščine kot tujega jezika in nastaja v okviru bilateralnega sodelovanja med Filozofsko fakulteto v Ljubljani in Filološko fakulteto v Beogradu. Projekt $z$ naslovom »Strategije formalnega učenja tujih jezikov v Sloveniji in Srbiji: jezikovna politika in jezikovna stvarnost« se je pričel izvajati s prvim krogom testiranj s testnimi kompleti CILS $^{1}$ konec študijskega leta 2009/10 (preostali testiranji sledita v naslednjih dveh letih).

Eden njegovih ciljev je določiti raven znanja študentov in ugotoviti, ali se ujema $\mathrm{z}$ ravnjo, ki smo jo predvideli za posamezni letnik (od B1 do C2, po Skupnem evropskem jezikovnem okviru, 2001). ${ }^{2}$ Članek predstavlja nekatere rezultate testiranj bralnega in slušnega razumevanja ter rabe jezikovnih struktur (slovničnih in leksikalnih) v vseh štirih letnikih italijanistike v Ljubljani. ${ }^{3}$

Osredotoča se na to, ali so študenti italijanskega jezika in književnosti na FF v Ljubljani dosegli ustrezno raven znanja, predvideno za vsakega od štirih letnikov, in skuša odgovoriti na vprašanje, koliko študij italijanskega jezika in književnosti prispeva k splošnemu znanju moderne italijanščine. Izhajamo iz naslednjih tez, ki

\footnotetext{
Prednosti mednarodnih testov CILS so številne, naj izpostavim predvsem to, da so plod izkušene ekipe strokovnjakov z Univerze v Sieni, ki se s tem področjem ukvarja že desetletja, prav s preizkusi v skladu s SEJO pa že približno 15 let. Pripravijo, testirajo, uporabijo in analizirajo izpitne komplete dvakrat letno, kar naj bi tudi italijanistikama v projektu omogočilo širšo mednarodno primerjavo

2 Izsledke o znanju študentov italijanistike v Ljubljani bomo primerjati z izsledki v Beogradu. Nadaljnje raziskave pa se bodo osredotočile tudi na kritično presojo primernosti mednarodnih testov za rabo $\mathrm{v}$ Sloveniji ter primerjavo in morebitno uskladitev testiranja znanja moderne italijanščine kot tujega jezika z dvema tujima univerzama (Beograd in Siena). Raziskovalni skupini v sestavi red. prof. dr. Julijana Vučo, prof. dr. Mila Samardžić, mag. Saša Moderc za Filološko fakulteto v Beogradu (Srbija) in dr. Darja Mertelj in mag. Jana Kenda za Filozofsko fakulteto v Ljubljani (Slovenija) bodo izvajali testiranje po priznanih in uveljavljenih preskusih znanj, v sodelovanju s prof. dr. Monico Barni in njenimi sodelavci z Univerze v Sieni (Italija). Zaenkrat v raziskavo niso zajeti neuniverzitetni učenci italijanščine (srednješolci, osnovnošolci)..

3 Rezultati pisnega in ustnega sporočanja, ki se $\mathrm{v}$ okviru raziskave tudi preverjata, $\mathrm{v}$ tem prispevku ne bodo predstavljeni.
} 
jih pri tem prvem testiranju postavljamo zgolj na podlagi izkušenj z generacijami študentov v zadnjih 10 letih:

1. Študenti italijanskega jezika in književnosti v Ljubljani bodo pri preverjanju slušnega in bralnega razumevanja ter jezikovnih struktur dosegli ustrezne ravni znanja po SEJO, in sicer 1. letniki raven B1, 2. letniki raven B2, 3. letniki raven $\mathrm{C} 1$ in 4 . letniki raven $\mathrm{C} 2$.

2. Pri bralnem razumevanju bodo rezultati nadpovprečni v vseh letnikih, saj se ta zmožnost, pa čeprav pogosto le implicitno, razvija pri večini študijskih predmetov.

3. Pri slušnem razumevanju bodo slabše rezultate dosegli študenti nižjih letnikov, saj študijski program ne ponuja predmetov, kjer bi se kot primarni cilj urilo slušno razumevanje; kljub temu pa bo pri študentih, ki zaključujejo 3. oz. 4. letnik, opazen napredek, ker so dotlej izpostavljeni sorazmerno visokemu številu ur v italijanščini (pribl. 700 ur letno, podobno v bolonjskih programih prve stopnje). Pri slušnem razumevanju pričakujemo slabše rezultate kot pri bralnem.

4. Pri polah z jezikovnimi strukturami bodo študenti italijanistike v Ljubljani dosegli najvišje rezultate med petimi zmožnostmi, saj so v študijskem predmetniku sorazmerno močno zastopane morfosintaktične vsebine in menimo, da so študenti deležni kakovostnega vnosa, kar naj bi se odrazilo pri znanju.

\section{ZASNOVA IN METODOLOGIJA}

Mednarodne testne komplete CILS (standardizirani testi Univerze za tujce v Sieni) smo želeli uporabiti, ker imajo z njimi v Sieni dolgo tradicijo, predvsem pa strokovnjake, ki so znanstveno-strokovno sodelovali pri njihovem razvijanju (M. Vedovelli, M. Barni). K temu je pomembno prispevalo tudi dejstvo, da je testno gradivo pripravljeno po SEJO (2001), kar predstavlja pomemben skupni kod za usklajevanje in medsebojno razumevanje tistih, ki delujejo na področju merjenja znanja tujih jezikov (Strambi 2004: 191). Izsledki naj bi omogočili vpogled v pet zmožnosti. ${ }^{4}$

Pomembno prednost je predstavljalo za nas tudi dejstvo, da nam ni bilo potrebno izpeljati vseh $10 \mathrm{faz}$ procesa valutacije oz. ocenjevanja (gl. prikaz 1, cf. Stambi in Scaglioso 2004: 170), pač pa le drugo polovico, pri čemer je predvideno, da se bodo $\mathrm{v}$ času poteka projekta primerjale in uravnavale med obema partnerskima univerzama in občasno tudi $z$ Univerzo v Sieni. ${ }^{5}$

\footnotetext{
4 Poleg vertikalne dimenzije testov CILS, pripravljenih v skladu s SEJO, kjer gre za testiranje napredovanja jezikovnih kompetenc, nas bodo $\mathrm{v}$ prihodnje zanimale tudi horizontalne dimenzije (sovplivanja med materinščino naših študentov in italijanščino kot njihovim drugim/tujim jezikom, konteksti in obsegi učenja italijanščine pred in med študijem, neformalni oz. obštudijski stiki naših študentov z italijanščino in družbeno-jezikovni dejavniki (kot so spol, družbeno-kulturni pogoji, motivacija ipd.).

5 Za testiranje je bil uporabljen komplet iz decembra 2009, ki še ni bil objavljen in ne bo še nadaljnja tri leta. Priprava testnih kompletov za presojanje jezikovnega znanja je kompleksen in dolgotrajen proces, ki ga izvaja skupina strokovnjakov. Testni kompleti CILS, ki smo jih brezplačno dobili v uporabo pred njihovo javno objavo, so dragocen nabor orodja, ki je raziskovalnima skupinama obeh partnerskih univerz omogočil pričetek raziskav.
} 
Prikaz 1: Faze procesa ocenjevanja pri testiranjih za pridobitev mednarodnib certifikatov

1. določiti cilj oz. cilje,

2. opredeliti vsebino/e,

3. pretvoriti cilje in vsebine v naloge, kjer jih je mogoče opazovati in preverjati,

4. pripraviti konkretne testne naloge oz. strukturirane komplete testnih nalog,

5. določiti kriterije popravljanja in točkovanja,
6. izvesti testiranje,

7. popraviti testne komplete in naloge

8. točkovati glede na predhodno opredeljene kriterije,

9. interpretirati izsledke,

10. določiti in izpeljati ukrepe, analizirati uporabljene testne pole.

Ker univerzitetni način študija predvideva tudi veliko samostojnega dela in je zasnovan na sorazmerno zahtevni ravni, smo menili, da je raven B1 (po SEJO) lahko primerno izhodišče za študente prvega letnika. Raven B namreč že označuje oz. predpostavlja neodvisnega uporabnika jezika, sporazumevalno avtonomnega v vsakdanjih kontekstih. ${ }^{6}$

Izhodiščno znanje na ravni B1 študentu omogoča, da tekom študija razvija svoje znanje do ravni B2, postopoma preide na raven $\mathrm{C} 1$ in marsikdo do zaključka študija tudi na raven C2 (vemo seveda, da je med študenti tudi kdo, ki je že v nižjih letnikih npr. na stopnji C1, po SEJO 2001).

Poleg tega je bila raven B1 kot izhodiščna raven za 1. letnike izbrana tudi zaradi besedišča, saj ne predpostavlja rabe okrnjenega nabora leksikalnih izrazov, kar je značilno za ravni A1 in A2 (prvih 850 oz. 1200 italijanskih besed od 7000 najpogostejših italijanskih, cf. De Mauro 1980), pač pa (potencialno) celoten nabor besed glede na Vocabolario di Base (De Mauro 1980). To implicitno pomeni tudi, da nabor tipov besedil ni omejen: poleg pripovednih, opisnih in usmerjevalnih besedil se uporabljajo tudi utemeljevalna besedila, ki vsekakor sodijo na področje visokošolskega študija.

Testi od ravni B1 do C2 so sestavljeni po enakem ključu: gre za testiranje petih zmožnosti s petimi testnimi polami, s katerimi se preverja sposobnost študenta, da italijanščino kot tuji jezik razume ter (pre)pozna in pravilno uporablja jezikovne strukture $v$ različnih kontekstih in sobesedilih. ${ }^{7}$

Maja 2010 smo na obeh univerzah izvedli testiranje v vseh štirih letnikih in sicer preverjali vseh pet zmožnosti: razumevanje govornih in pisnih besedil, obvladovanje jezikovnih struktur (ital. strutture di comunicazione) s slovničnimi in besediščnimi nalogami, ter bralno in pisno izražanje), poleti je potekalo ocenjevanje testnih pol za tri zmožnosti (razen pisnega in govornega izražanja, ki ju bo ocenjevalo večje število ocenjevalcev). $V$ nadaljevanju je predstavitev rezultatov in deloma njihova interpretacija. ${ }^{8}$

\footnotetext{
6 Čeprav soavtorji teh testnih kompletov menijo, da imata lahko orientacijsko, motivacijsko in diagnostično težo predvsem testa za obe začetniški ravni A1 in A2 (Strambi 2004: 190), menimo, da so študenti dovolj zreli, da lahko v takih funkcijah sprejemajo svoje rezultate testov tudi na ostalih ravneh.

7 Le deloma oz. implicitno se pri nekaterih nalogah ob ustrezni analizi pokažejo tudi znanja, ki jih študent pridobi pri določenih predmetih med univerzitetnim študijem.

8 Faza določitve in izpeljave ukrepov se bo predvidoma izvajala od študijskega leta 2010/2011 dalje, vendar le na določenih področjih (besedišče, glagolski časi, skladnje večstavčnih povedi). Zadnja faza, tj. analiza testnih pol, se predvidoma ne bo izvajala, dokler se ne izvedeta še nadaljnji dve testiranji maja 2011 in maja 2012.
} 


\section{PREGLED IZSLEDKOV}

V testih študenti so reševali predvsem naloge objektivnega tipa (ital. prove oggettive) in le $\mathrm{v}$ manjšem obsegu delno objektivnega tipa (ital. prove semistrutturate), slednje so se pojavile predvsem pri poli z jezikovnimi struktura$\mathrm{mi}$, pri ravneh $\mathrm{C} 1$ in $\mathrm{C} 2$. Vse tri omenjene pole vsebujejo naloge integrativnega tipa (test integrati), kar pomeni, da ne gre za preverjanje posamičnih jezikovnih elementov, pač pa je za uspeh nujno, da študent kontekst in besedila razume, zatem pa smiselno uporabi oz. kombinira veliko svojih jezikovnih znanj v danih okoliščinah.

Do izsledkov smo prišli z upoštevanjem točkovalnika za CILS in manjšega števila dodatnih smiselnih rešitev (samo pri polah z jezikovnimi strukturami, predvsem na ravneh $\mathrm{C} 1$ in $\mathrm{C} 2$ ), ki so bili dodatno usklajeni z lektorico za italijanščino na Oddelku za romanske jezika in književnosti (Filozofske fakultete $\mathrm{v}$ Ljubljani). ${ }^{9}$

$\mathrm{V}$ nadaljevanju so predstavljeni in komentirani nekateri rezultati, ki so jih dosegli naši študenti, in sicer dosežene povprečne vrednosti pri posamični zmožnosti, razponi pri rezultatih in nekateri vidiki pri posamičnih polah (glede jezikovnih struktur in glede besedišča).

\subsection{Prvi letniki - B1 - bralno in slušno razumevanje, jezikovne strukture}

Testiranja se je udeležilo 26 študentov, ki so maja 2010 zaključevali prvo leto študija italijanistike. Raven, ki smo jo določili kot izhodiščno, je bila nižja srednja raven $\mathrm{B} 1$ po SEJO.

Odločili smo se, da bomo študentom prvega letnika ponudili test na ravni B1 tudi zato, ker menimo, da so v prvem letniku izpostavljeni tolikšni količini ur v italijanščini in tolikšni zahtevnosti vsebin, da so primorani samostojno razvijati receptivna znanja (predvsem pri nadgrajevanju začetnega znanja). Redna izpostavljenost študijskim predmetom in samostojno delo po našem mnenju usposabljata celo študente brez ustreznega predznanja ob pričetku študija (ki so npr. na ravni A1 ali A2) za uspešno reševanje testov na ravni B1. ${ }^{10}$

\footnotetext{
9 Lekt. Eleonora Kolar je tudi izkušena izvajalka testiranj CELI in CILS, od jeseni 2009 tudi na Italijanskem inštitutu za kulturo v Ljubljani.

10 Bodočim študentom prvega letnika priporočamo, naj ne pričenjajo študija brez ali z zelo nizkim predznanjem (A1), vendar delež tovrstnih študentov vseeno narašča: spodbujamo jih k rednemu opravljanju študijskih obveznosti in tudi k samostojnemu učenju italijanščine.
} 
Prikaz 2: CILS 2010 - B1 - bralno in slušno razumevanje, jezikovne strukture, 26 študentov

\begin{tabular}{|c|c|c|}
\hline $\begin{array}{l}\text { BRALNO RAZUMEVANJE - } \\
\text { B1 }\end{array}$ & $\begin{array}{c}\text { SLUŠNO RAZUMEVANJE - } \\
\text { B1 }\end{array}$ & $\begin{array}{c}\text { JEZIKOVNE STRUKTURE - } \\
\text { B1 }\end{array}$ \\
\hline $\begin{array}{c}\text { पnad } 80 \% \\
\square 70-80 \% \\
\square \text { pod } 70 \% \\
\begin{array}{c}\text { ase niso } \\
\text { udelezili }\end{array}\end{array}$ & $\begin{array}{l}\square \text { nad } 80 \% \\
\text { प70-80\% } \\
\text { प pod } 70 \% \\
\begin{array}{c}\text { Dse niso } \\
\text { udelezili }\end{array}\end{array}$ & $\begin{array}{c}\square \text { nad } 80 \% \\
\square 70-80 \% \\
\square \text { pod } 70 \% \\
\square \text { se niso } \\
\text { udelezili }\end{array}$ \\
\hline
\end{tabular}

Dejansko so se ta pričakovanja pri prvih letnikih glede obeh receptivnih zmožnosti potrdila, čeprav z nižjimi rezultati od pričakovanih: samo en testirani študent ni dosegel $50 \%$ (individualno povprečje je imel $49 \%$ ).

\section{Bralno razumevanje - $B 1$}

Č pogledamo rezultate po posamični od treh zmožnosti, lahko ugotovimo, da so rezultati pri bralnem razumevanju sicer v povprečju visoki $(77 \%)$, vendar $\mathrm{v}$ velikem razponu, in sicer od $26 \%$ do $100 \%$ (gl. prikaz 3).

Prikaz 3: CILS 2010 - B1 - bralno razumevanje, 26 študentov FF

BRALNO - nad $70 \%$

\begin{tabular}{|l|c|c|}
\hline Zap. št. & Šifra štud. & Ocena v $\%$ \\
\hline 1. & 9 & 100 \\
\hline 2. & 3 & 95 \\
\hline 3. & 25 & 95 \\
\hline 4. & 22 & 91 \\
\hline 5. & 12 & 90 \\
\hline 6. & 18 & 90 \\
\hline 7. & 4 & 88 \\
\hline 8. & 7 & 88 \\
\hline 9. & 15 & 86 \\
\hline 10. & 17 & 86 \\
\hline 11. & 6 & 85 \\
\hline 12. & 23 & 84 \\
\hline 13. & 10 & 83 \\
\hline 14. & 13 & 83 \\
\hline 15. & 5 & 81 \\
\hline 16. & 24 & 77 \\
\hline 17. & 19 & 76 \\
\hline
\end{tabular}

BRALNO - pod $70 \%$

\begin{tabular}{|l|c|c|}
\hline Zap. št. & Šifra štud. & Ocena $\mathbf{v} \%$ \\
\hline 18. & 8 & 67 \\
\hline 19. & 26 & 67 \\
\hline 20. & 1 & 61 \\
\hline 21. & 14 & 56 \\
\hline 22. & 2 & 50 \\
\hline 23. & 21 & 45 \\
\hline 24. & 20 & 26 \\
\hline 25. & 11 & $/$ \\
\hline 26. & 16 & $/$ \\
\hline
\end{tabular}


Kar 15 študentov prvega letnika je doseglo rezultat nad 80 \%, kar je povsem primerno - na marsikateri italijanistiki po Evropi ali v svetu bi ga označili celo kot nadpovprečen rezultat. Vendar pa bodo študenti z rezultatom pod $80 \%$ verjetno imeli težave pri študiju, saj so bila besedila za bralno razumevanje na ravni B1 sorazmerno enostavna. ${ }^{11}$

\section{Slušno razumevanje - $\mathbf{B} 1$}

Proti pričakovanjem se je pokazalo, da slušno razumevanje besedil na ravni B1 ne povzroča težav: $\mathrm{v}$ povprečju so študenti dosegli visok rezultat ( $80 \%)$, vsi nad $50 \%$, in sicer od $53 \%$ do $93 \%$ (gl. prikaz 4). Vsekakor je kar 20 študentov od 22 doseglo rezultat nad $70 \%$, kar je več kot zadovoljivo (le 2 študenta sta dosegla 53 oz. $55 \%$ ). Taki izsledki potrjujejo, da so bila besedila na tej stopnji sorazmerno enostavna (kar so ustno komentirali tudi študenti sami). ${ }^{12}$

Prikaz 4: CILS 2010 - B1 - slušno razumevanje, 26 študentov FF

\begin{tabular}{|l|c|c|}
\multicolumn{4}{|c}{ SLUŠNO - nad $\mathbf{7 0} \%$} \\
\hline Zap. št. & Šifra štud. & ocena v $\%$ \\
\hline 1. & 22 & 93 \\
\hline 2. & 25 & 91 \\
\hline 3. & 18 & 91 \\
\hline 4. & 4 & 91 \\
\hline 5. & 13 & 88 \\
\hline 6. & 7 & 88 \\
\hline 7. & 24 & 86 \\
\hline 8. & 9 & 86 \\
\hline 9. & 5 & 86 \\
\hline 10. & 6 & 85 \\
\hline 11. & 3 & 85 \\
\hline 12. & 12 & 81 \\
\hline 13. & 10 & 80 \\
\hline 14. & 8 & 79 \\
\hline 15. & 23 & 76 \\
\hline 16. & 15 & 76 \\
\hline 17. & 20 & 75 \\
\hline 18. & 2 & 75 \\
\hline 19. & 21 & 73 \\
\hline 20. & 19 & 72 \\
\hline
\end{tabular}

SLUŠNO - pod $70 \%$

\begin{tabular}{|l|c|c|}
\hline Zap. št. & Šifra štud. & Ocena v \% \\
\hline 21. & 14 & 56 \\
\hline 22. & 1 & 53 \\
\hline 23. & 26 & $/$ \\
\hline 24. & 17 & $/$ \\
\hline 25. & 16 & $/$ \\
\hline 26. & 11 & $/$ \\
\hline
\end{tabular}

11 Morebitna zahtevnejša oz. specifičnejša besedila bi verjetno povzročila še več težav. V okviru projekta je predvideno tudi longitudinalno spremljanje in tovrstno testiranje študentov do konca študija, ko bo možno take teze tudi preveriti.

12 Lahko pa bi rezultate interpretirali tudi tako, da bi z njimi ovrgli sicer pogoste očitke študentov, ki menijo, da bi potrebovali predmet, kjer bi urili predvsem slušno razumevanje. Ker bo projekt trajal še 2 leti in se bodo testiranja še izvajala, bomo morda lahko prišli do bolj relevantnih zaključkov glede potrebe, da bi se zmožnosti razvijanja slušnega razumevanja namenilo posebno pozornost. 


\section{Jezikovne strukture - B1}

Pri poli z jezikovnimi strukturami na ravni B1 smo pričakovali, da bodo študenti enostavne naloge (naloga s sorazmerno enostavnimi rabami člena in očlenjenih predlogov, naloga $\mathrm{z}$ majhnim naborom glagolskih oblik, naloga za besedišče na receptivni ravni) zlahka in $\mathrm{v}$ veliki večini pravilno rešili.

Vendar ni bilo tako: rezultati pri strukturah $\mathrm{v}$ povprečju dosegajo komaj $70 \%$. Razpon se prične pri komaj $47 \%$ (gl. prikaz 5), le polovica študentov je dosegla rezultat nad $70 \%$, pri čemer je bila ena naloga $\mathrm{v}$ poli (izbor med štirimi govornimi dejanji za dani kontekst) tako enostavna, da je vsem znatno dvignila povprečje (v večini so namreč pri tej nalogi dosegli $100 \%$, cf. Mertelj v pripravi).

Prikaz 5: CILS 2010 - B1 - jezikovne strukture, 26 študentov FF

\section{STRUKTURE - nad $70 \%$}

\begin{tabular}{|l|c|c|}
\hline Zap. št. & Šifra štud. & Ocena v $\%$ \\
\hline 1. & 11 & 92 \\
\hline 2. & 12 & 87 \\
\hline 3. & 9 & 85 \\
\hline 4. & 4 & 84 \\
\hline 5. & 16 & 84 \\
\hline 6. & 19 & 80 \\
\hline 7. & 22 & 79 \\
\hline 8. & 3 & 78 \\
\hline 9. & 23 & 76 \\
\hline 10. & 7 & 73 \\
\hline 11. & 5 & 72 \\
\hline 12. & 18 & 72 \\
\hline 13. & 8 & 70 \\
\hline 14. & 24 & 70 \\
\hline
\end{tabular}

Približno polovica študentov (ki ni dosegla $70 \%$ ) bo verjetno imela težave pri študiju, saj gre za sorazmerno enostavne strukture, ki jih bodo morali pri določenih predmetih bolje obvladati že za vstop v 2 . letnik študija.

\subsection{Drugi letniki - B2 - bralno in slušno razumevanje, jezikovne strukture}

Prikazi, ki se nanašajo na skupino 2. letnika (gl. prikaza 6a in 6b), so precej nerealni, saj se je testiranja zaradi objektivne odsotnosti udeležilo le šest študentov (od tega trije taki, ki študirajo italijanščino že štiri leta in so ponavljali tako prvi 
kot drugi letnik). Zaradi tega rezultati nimajo večje orientacijske ali napovedne vrednosti, kar bo pa morda pokazala primerjava s testiranji po drugem letniku v naslednjih dveh letih projekta. Vsekakor pa je vseh šest študentov doseglo individualna povprečja višja od $50 \%$.

Prikaz 6a: CILS 2010 - B2 - bralno in slušno razumevanje, jezikovne strukture, 6 študentov

\begin{tabular}{|c|c|c|c|c|}
\hline \multicolumn{2}{|c|}{$\begin{array}{l}\text { BRALNO RAZUMEVANJE - } \\
\text { B2 }\end{array}$} & \multicolumn{2}{|c|}{$\begin{array}{c}\text { SLUŠNO RAZUMEVANJE - } \\
\text { B2 }\end{array}$} & $\begin{array}{c}\text { JEZIKOVNE STRUKTURE - } \\
\text { B2 }\end{array}$ \\
\hline 3 & $\begin{array}{c}\square \text { nad } 80 \% \\
\square 70-80 \% \\
\square \text { pod } 70 \% \\
\text { ase niso } \\
\text { udelezili }\end{array}$ & & \begin{tabular}{|l}
$\square$ nad $80 \%$ \\
$\square 70-80 \%$ \\
$\square$ pod $70 \%$ \\
$\square$ se niso \\
udelezili
\end{tabular} & $\begin{array}{l}\square \text { nad } 80 \% \\
\square 70-80 \% \\
\square \text { pod } 70 \% \\
\begin{array}{c}\text { ase niso } \\
\text { udelezili }\end{array}\end{array}$ \\
\hline
\end{tabular}

Najboljše rezultate je šesterica testirancev iz 2. letnika dosegla pri bralnem razumevanju (skupno povprečje je bilo $81 \%$ ), sicer pa vsi v razponu od 71 \% do 90 $\%$, kar so povsem primerni rezultati (gl. prikaz $6 \mathrm{~b}$ ). Slušno razumevanje je bilo na ravni B2 zahtevnejše kot bralno: primerno visokih rezultatov niso dosegli ponavljavci (ki so pravzaprav izpostavljeni časovno podvojenemu poslušanju in nezavednemu usvajanju govorjene italijanščine), pač pa tisti, ki so redno študirali in se vpisali v 2. letnik. To je pravzaprav pričakovano: študenti, ki so imeli ob pričetku študija več jezikovnega predznanja lahko razvijajo boljše slušno razumevanje tudi prek drugih zmožnosti in znanj (ter pogosto v neformalnem stiku z govorjeno italijanščino prek medijev).

Prikaz 6b: CILS 2010 - B2 - bralno in slušno razumevanje, jezikovne strukture, 6 študentov

\begin{tabular}{|} 
BRALNO - vsi nad $70 \%$ \\
\hline & 1 & 90 \\
\hline & 6 & 88 \\
\hline & 5 & 87 \\
\hline & 3 & 79 \\
\hline & 4 & 73 \\
\hline & 2 & 71 \\
\hline
\end{tabular}

\begin{tabular}{|c|c|c|}
\hline \multicolumn{3}{|c|}{ SLUŠNO - nad $70 \%$} \\
\hline & 1 & 95 \\
\hline & 6 & 85 \\
\hline & 5 & 77 \\
\hline
\end{tabular}

SLUŠNO - pod 70 \%
\begin{tabular}{|c|c|c|}
\hline & 4 & 67 \\
\hline & 2 & 47 \\
\hline & 3 & 32 \\
\hline
\end{tabular}

STRUKTURE - nad $70 \%$

\begin{tabular}{|l|l|l|}
\hline & 1 & 86 \\
\hline & 2 & 76 \\
\hline
\end{tabular}

STRUKTURE - pod $70 \%$

\begin{tabular}{|c|c|c|}
\hline & 3 & 65 \\
\hline & 4 & 64 \\
\hline & 5 & $/$ \\
\hline & 6 & $/$ \\
\hline
\end{tabular}

Testiranje jezikovnih struktur je opravila le četverica študentov, sicer s skupnim povprečjem 73 \%, vendar je vzorec premajhen, da bi lahko o čemerkoli sklepali, zaključevali ali primerjali več kot zgolj individualne primere. 


\subsection{Tretji letniki - C1 - bralno in slušno razumevanje, jezikovne strukture}

Tretji letniki v 2009-2010 so bili solidna skupina študentov, v večini so nadpovprečno zainteresirani in sorazmerno aktivno delajo, kar se je odrazilo tudi na testiranju CILS na ravni C1. Udeležilo se ga je zaradi drugih obveznosti sicer le deset študentov (dejansko jih je vpisanih več).

Vsi testirani študenti tretjega letnika so v okviru ravni C1 dosegli rezultate nad $70 \%$. Če primerjamo uspešnost pri bralnem $z$ uspešnostjo pri slušnem razumevanju, ugotovimo, da so pri slednjem študenti dosegli boljše rezultate, celo nad $80 \%$ (gl. prikaza $7 \mathrm{a}$ in $7 \mathrm{~b}$ ).

Pri ravni $\mathrm{C}$ je iz nabora nalog oz. besedil za bralno razumevanje odstranjen narek (ki ga vsebujeta testa na ravni B). Namesto tega je v vsako izmed pol vključeno po eno sorazmerno zahtevno besedilo iz t. i. birokratskega jezika (besedila italijanskih javnih razpisov s sorazmerno visoko gostoto informacij in specifičnimi besediščnimi izrazi), kar je precej otežilo razumevanje besedil oz. doseganje visokih točk. S podobnega področja besedil je bila tudi zadnja naloga pri poli z jezikovnimi strukturami, kjer je bilo potrebno izvesti skladenjsko pretvarjanje povedi z zahtevnejšim birokratskim jezikom.

Prikaz 7a: CILS 2010 - C1 - bralno in slušno razumevanje, jezikovne strukture, 10 študentov

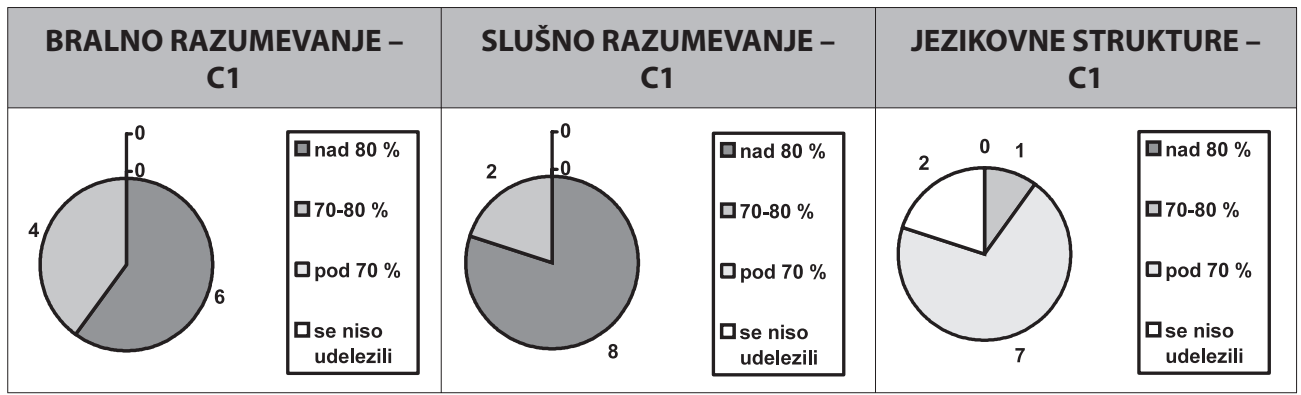

Pri bralnem razumevanju so študenti dosegli v povprečju $81 \%$, pri slušnem pa celo $86 \%$. V celotnem letniku ni bilo niti enega študenta, ki bi imel individualno povprečje pod $70 \%$, vendar je slika o znanju jezika na tej ravni precej drugačna pri rezultatih testiranja jezikovnih struktur (gl. prikaza $7 \mathrm{a}$ in $7 \mathrm{~b}$ ). 
Prikaz 7b: CILS 2010 - C1 - bralno in slušno razumevanje, jezikovne strukture, 10 študentov

\begin{tabular}{|c|c|}
\hline BRALNO - vs & $0 \%$ \\
\hline 8 & 91 \\
\hline 5 & 88 \\
\hline 2 & 86 \\
\hline 1 & 81 \\
\hline 3 & 81 \\
\hline 9 & 81 \\
\hline 10 & 77 \\
\hline 6 & 76 \\
\hline 7 & 76 \\
\hline 4 & 74 \\
\hline
\end{tabular}

\begin{tabular}{|} 
SLUŠNO - vsi nad $70 \%$ \\
\hline & 9 & 100 \\
\hline & 10 & 97 \\
\hline & 5 & 90 \\
\hline & 2 & 87 \\
\hline & 7 & 87 \\
\hline & 1 & 82 \\
\hline & 4 & 82 \\
\hline & 6 & 81 \\
\hline & 3 & 76 \\
\hline & 8 & 76 \\
\hline
\end{tabular}

STRUKTURE - nad $70 \%$

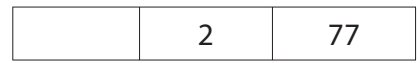

STRUKTURE - pod $70 \%$

\begin{tabular}{|c|c|c|}
\hline & 4 & 68 \\
\hline & 3 & 63 \\
\hline & 5 & 63 \\
\hline & 7 & 61 \\
\hline & 8 & 59 \\
\hline & 6 & 58 \\
\hline & 1 & 52 \\
\hline & 9 & $/$ \\
\hline & 10 & $/$ \\
\hline
\end{tabular}

Pri jezikovnih strukturah je skupno povprečje sicer $63 \%$, toda rezultati študentov se gibljejo v razponu od $52 \%$ do komaj $77 \%$ pri najboljšem izmed njih (gl. prikaz 7b). Menimo, da so taki rezultati prenizki: vzrok zanje je predvsem (zahtevna) naloga, kjer je bilo potrebno izkazati pravilno razumevanja sobesedila, poiskati ustrezen pomen glagolov in jih uporabiti v skladu s svojim znanjem rabe glagolskih časov. Pri tej nalogi je bilo povprečje 59 \%, razpon pa od 45 do 73 \%, kar se nam zdi nekoliko zaskrbljujoče.

Rezultati nakazujejo, da bi se morda lahko vsebine in načine, ki se uporabljajo med študijem pri obravnavanju rab glagolskih časov, do neke mere lahko spremenilo. Tako bi študenti imeli pri produktivni rabi glagolskih oblik priložnost pokazati, da obvladajo prenos kakovostne teorije $\mathrm{v}$ rabo sodobne italijanščine.

\section{4. Četrti letniki - C2 - bralno in slušno razumevanje, jezikovne strukture}

Kot že omenjeno, so tudi pole za bralno razumevanje na ravni C2 vsebovale sorazmerno zahtevno besedilo iz t. i. birokratskega jezika, ki je bilo seveda še zahtevnejše kot pri poli za C1. S podobnega besedilnega področja je bila tudi zadnja naloga pri poli z jezikovnimi strukturami, ki je predstavljala res trd oreh: predvideno skladenjsko pretvarjanje povedi je bilo tako zahtevno, da tega po mnenju italijanske lektorice ne bi zmogla niti večina rojstnih govorcev italijanščine.

Slušno razumevanje je bilo zahtevno zaradi precej nejasne vsebine: naloga je zatem zahtevala od študentov ne le pozorno povezovanje in kombiniranje informacij, pač pa tudi interpretacijo in predvsem izločanje posamičnih odtenkov pomena.

Zaradi navedenega lahko opazimo, da so četrti letniki v okviru ravni C2 dosegli nekoliko nižje rezultate kot tretji letniki (prim. prikaza 7a in 8a), in sicer pri bralnem razumevanju v povprečju $77 \%$, povprečje pri slušnem razumevanju 
pa je bilo 69 \% (razpon je bil od $52 \%$ do komaj $83 \%$, gl. prikaz 8b). Jezikovne strukture so bile daleč najtrši oreh, povprečje skupine je bilo komaj $59 \%$, le dva študenta sta dosegla nekaj nad $70 \%$, vsi ostali med $35 \%$ in $69 \%$ (gl. prikaz 8b). Med 11 študenti je bil eden tudi negativen s skupnim individualnim rezultatom $46 \%$.

Prikaz 8a: CILS 2010 - C2 - bralno in slušno razumevanje, jezikovne strukture, 11 študentov

\begin{tabular}{|c|c|c|c|}
\hline $\begin{array}{c}\text { BRALNO RAZUMEVANJE - } \\
\text { C2 }\end{array}$ & \multicolumn{2}{c|}{$\begin{array}{c}\text { SLUŠNO RAZUMEVANJE - } \\
\text { C2 }\end{array}$} \\
\hline C2
\end{tabular}

Rezultati so sicer za raven C2 sorazmerno dobri, saj so bile številne naloge v testiranjih teh treh zmožnosti resnično zahtevne in so pogosto predpostavljale upoštevanje tudi slogovnih zahtev, ne le zgolj slovničnih pravil.

Zlasti se je slednje odrazilo pri poli za testiranje jezikovnih struktur, kjer je šlo pri prvem, mešanem besedilu z vrzelmi (ang. cloze) za slogovno zahtevno besedilo Umberta Eca, naloga izbiranja ustreznega besedišča je vsebovala tudi rešitve, ki so izven najpogostejših 7000 italijanskih besed, skladenjske pretvorbe so bile izjemno kompleksne in so predpostavljale brezhibno razumevanje birokratskega jezika.

Prikaz 8b: CILS 2010 - C2 - bralno in slušno razumevanje, jezikovne strukture, 11 študentov

BRALNO - nad $70 \%$

\begin{tabular}{|l|c|c|}
\hline 1. & 5 & 98 \\
\hline 2. & 1 & 93 \\
\hline 3. & 3 & 83 \\
\hline 4. & 10 & 82 \\
\hline 5. & 4 & 78 \\
\hline 6. & 6 & 78 \\
\hline 7. & 8 & 78 \\
\hline 8. & 11 & 72 \\
\hline
\end{tabular}

BRALNO - pod $70 \%$

\begin{tabular}{|l|l|l|}
\hline 9. & 9 & 58 \\
\hline 10. & 7 & 47 \\
\hline 11. & 2 & $/$ \\
\hline
\end{tabular}

SLUŠNO nad $70 \%$

\begin{tabular}{|c|c|c|}
\hline 1. & 1 & 83 \\
\hline 2. & 11 & 79 \\
\hline 3. & 3 & 77 \\
\hline 4. & 10 & 77 \\
\hline 5. & 5 & 75 \\
\hline 6. & 2 & 73 \\
\hline 7. & 6 & 70 \\
\hline
\end{tabular}

SLUŠNO - pod $70 \%$

\begin{tabular}{|l|l|l|}
\hline 8. & 8 & 64 \\
\hline 9. & 4 & 57 \\
\hline 10. & 7 & 55 \\
\hline 11. & 9 & 52 \\
\hline
\end{tabular}

STRUKTURE nad $70 \%$

\begin{tabular}{|l|c|c|}
\hline 1. & 1 & 74 \\
\hline 2. & 10 & 73 \\
\hline
\end{tabular}

STRUKTURE pod $70 \%$

\begin{tabular}{|l|c|c|}
\hline 3. & 3 & 69 \\
\hline 4. & 9 & 62 \\
\hline 5. & 5 & 62 \\
\hline 6. & 4 & 58 \\
\hline 7. & 2 & 58 \\
\hline 8. & 8 & 57 \\
\hline 9. & 6 & 44 \\
\hline 10. & 7 & 35 \\
\hline 11. & 11 & $/$ \\
\hline
\end{tabular}




\section{UGOTOVITVE IN NADALJNJE TEZE}

Po prvem od triletnega cikla testiranj študentov od 1. do 4. letnika študija italijanistike smo izhajali iz štirih hipotez, ki zadevajo testiranje treh od petih zmožnosti (bralno razumevanje, slušno razumevanje, jezikovne strukture: slovnične strukture in besedišče). Uporabili smo mednarodne testne komplete Univerze $v$ Sieni (CILS). V prikazu 9 so navedene posamične hipoteze in ugotovitve, povezane z njimi.

Prikaz 9: Hipoteze in ugotovitve / zaključki za 2009-2010

\begin{tabular}{|c|c|}
\hline Hipoteza & Ugotovitve oz. zaključki za 2009-2010 \\
\hline $\begin{array}{l}\text { 1. } \\
\text { Študenti italijanskega jezika in književnosti } \\
\mathrm{v} \text { Ljubljani bodo pri preverjanju slušnega in } \\
\text { bralnega razumevanja ter jezikovnih struktur } \\
\text { dosegli ustrezne ravni znanja po SEJO, in sicer } \\
\text { 1. letniki raven } B 1 \text {, 2. letniki raven } B 2,3 \text {. letniki } \\
\text { raven } C 1 \text { in } 4 \text {. letniki raven } C 2 \text {. }\end{array}$ & $\begin{array}{l}\text { Drži, } \\
\text { glede vseh treh preizkusov od petih } \\
\text { (glede študentskih povprečnih vrednosti). } \\
\text { Samo dva študenta pri posamičnih polah } \\
\text { nista presegla } 50 \% \text {, in sicer } \\
\text { en študent v 1. letniku (49\%) } \\
\text { in en študent v } 4 \text {. letniku (46\%). }\end{array}$ \\
\hline $\begin{array}{l}2 . \\
\text { Pri bralnem razumevanju bodo rezultati } \\
\text { nadpovprečni v vseh letnikih, saj se ta } \\
\text { zmožnost, pa čeprav pogosto le implicitno, } \\
\text { razvija pri večini študijskih predmetov. }\end{array}$ & $\begin{array}{l}\text { Drži, } \\
\text { v povprečju so rezultati visoki } \\
(77 \%, 81 \%, 81 \%, 77 \%,- \text { povprečno } 79 \%), \\
\text { pri bralnem razumevanju so povprečja višja } \\
\text { kot pri ostalih dveh zmožnostih. }\end{array}$ \\
\hline $\begin{array}{l}3 . \\
\text { Pri slušnem razumevanju bodo slabše } \\
\text { rezultate dosegli študenti nižjih letnikov, saj } \\
\text { študijski program ne ponuja predmetov, kjer } \\
\text { bi se kot primarni cilj urilo slušno razumevanje; } \\
\text { kljub temu pa bo pri študentih, ki zaključujejo } \\
\text { 3. oz. 4. letnik, opazen napredek, ker so dotlej } \\
\text { izpostavljeni sorazmerno visokemu številu } \\
\text { ur v italijanščini (pribl. } 700 \text { ur letno, podobno } \\
\text { v bolonjskih programih prve stopnje). Pri } \\
\text { slušnem razumevanju pričakujemo slabše } \\
\text { rezultate kot pri bralnem. }\end{array}$ & $\begin{array}{c}\text { Ne drži, } \\
\text { pri slušnem razumevanju so rezultati dokaj } \\
\text { različni, in sicer } \\
\text { 1. letniki } 80 \% \text {, 2. letniki } 67 \% \text {, } \\
\text { 3. letniki } 86 \% \text {, 4. letniki } 69 \% \text {. } \\
\text { Iz tega ne moremo zaključiti, da so se nižji } \\
\text { letniki bistveno slabše odrezali od višjih, } \\
\text { čeprav je skupno povprečje pri višjih letnikih } \\
\text { za } 4 \% \text { višje (73\% vs. 77\%). } \\
\text { Rezultat je v primerjavi z rezultatom pri } \\
\text { bralnem razumevanju nižji, a ne bistveno. }\end{array}$ \\
\hline $\begin{array}{l}4 . \\
\text { Pri polah z jezikovnimi strukturami bodo } \\
\text { študenti italijanistike v Ljubljani dosegli } \\
\text { najvišje rezultate med petimi zmožnostmi, } \\
\text { saj so v študijskem predmetniku sorazmerno } \\
\text { močno zastopane morfosintaktične vsebine in } \\
\text { menimo, da so študenti deležni kakovostnega } \\
\text { vnosa, kar naj bi se odrazilo pri znanju. }\end{array}$ & $\begin{array}{c}\text { Ne drži: } \\
\text { študenti vseh štirih letnikov so pri poli } \\
\text { z jezikovnimi strukturami dosegli } \\
\text { najnižje rezultate, in sicer: } \\
\text { 1. letniki } 70 \% \text {, 2. letniki } 73 \% \text {, } \\
\text { 3. letniki } 63 \% \text {, 4. letniki } 59 \% \text {. } \\
\text { Doseženi rezultati so v primerjavi z bralnim in } \\
\text { slušnim razumevanjem nižji za } 13 \% \text { oz. } 10 \% \text {. }\end{array}$ \\
\hline
\end{tabular}

V splošnem ugotavljamo, da so študenti pri testiranju treh zmožnosti dosegli sorazmerno dobre rezultate, vendar smo mnenja, da imajo posamične naloge v te- 
stnih polah morda prenizko zahtevnost, da bi lahko bili rezultati povsem ustrezna povratna informacija bodočemu diplomiranemu italijanistu oz. profesorju italijanščine.

Menimo, da bi bila primerna meja sprejemljivosti rezultatov naslednja: če je študent dosegel rezultate nad 80 \% (v svojih individualnih povprečjih ali pri posamični nalogi testne pole), je lahko zadovoljen in naj zgolj nadaljuje svoj način razvijanja in nadgrajevanja znanja moderne italijanščine.

Tisti, ki so dosegli rezultate med 70 in $80 \%$, bodo morali vložiti nekaj truda, toda verjetno bodo brez večjih težav zmogli samostojno razvijati svoje znanje italijanščine in svoje rezultate brez večjih naporov izboljšali zgolj s tem, da se nekoliko aktivneje ukvarjajo $\mathrm{z}$ italijanščino (npr. samostojno reševanje dodatnih nalog $\mathrm{s}$ področij, kjer so dosegli nižje odstotke, in zavestno povezovanje vaj s snovjo, ki se obravnava pri predmetih v sklopu študija).

Študenti, katerih individualno povprečje ali dosežek pri posamični poli ali pri posamični nalogi je nižji od $70 \%{ }^{13}$ po naši presoji ne morejo biti zadovoljni s svojim znanjem in bi morali pričeti s sistematičnim samostojnim učenjem ob ustreznih didaktičnih gradivih. ${ }^{14}$ Zgolj s sistematičnim, sorazmerno obsežnim in predvsem premišljenim samostojnim delom bodo študenti svoje rezultate izboljšali. Vsako leto bodo namreč testirani za eno stopnjo oz. raven znanja višje, kar pomeni, da naj bi izboljševali tako predhodno raven znanja kot tisto, ki je predvidena za tekoči letnik študija.

\subsection{Nadaljnje teze}

Testiranje študentov italijanistike nam deloma eksplicitno in deloma implicitno podaja precej relevantnih povratnih informacij, implicitno tudi o dosedanjih načinih (vidikih) podajanja snovi in razmišljanja gredo v smer vprašanja, kako bi lahko na osnovi rezultatov načine podajanja snovi spremenili tako, da bi se študenti vsebin s področja modernega italijanskega jezika bolje naučili in jih znali uporabiti.

Na podlagi izsledkov so se oblikovali načrti, usmerjeni predvsem v izboljšanje posamičnih kompetenc študentov, kar naj bi z ustreznimi ukrepi dosegli $\mathrm{v}$ naslednjih študijskih letih. Ukrepi so usmerjeni v intenziviranje obsega samostojnega dela študentov, ki predvideva tudi samostojno popravljanje svojih nalog in spremljanje svojega napredka, $v$ manjši meri pa tudi vključevanje določenih vsebin v obstoječe predmete prenovljenega bolonjskega programa, ki ga izvajamo od študijskega leta 2009/2010.

\footnotetext{
13 Rezultate pod 70 \% upoštevamo kot slabše, čeprav je za pripravljavce mednarodnih testiranj že rezultat nad 50 \% dovolj, da se nekomu prizna, da je dosegel določeno raven znanja, vendar gre v teh primerih za uporabnike jezika v širšem smislu, ki niso bodoči diplomirani italijanisti oz. profesorji italijanščine, za katere menimo, da morajo posedovati poleg raznolikih specifičnih znanj s področja italijanistike tudi visoko raven obvladanja italijanščine kot tujega jezika.

14 Pri tem bi bile za dodatno urjenje primerne tudi naloge, ki sodijo na nižjo raven znanja (na tržišču je v zadnjih desetih letih na voljo veliko raznolikih učnih gradiv primernih stopenj, ki jih taki študenti lahko s pridom uporabijo).
} 
Po prvih opravljenih analizah smo si za cilj zastavili, da z dodajanjem ustrezne snovi oz. poudarkov glede posamičnih tipov nalog (besedišče, slušno razumevanje, glagol, druge strukture) v naslednjih dveh letih študentom pomagamo, da pri polah za slušno in bralno razumevanje ter jezikovnih strukturah vsi dosežejo povprečje nad $70 \%$. V ta namen jih želimo usmeriti tudi k samostojnemu učenju, pri katerem bodo uporabljali učna gradiva, ki jih bodo predlagali učitelji na italijanistiki. ${ }^{15}$

\section{VIRI}

BARKI PAZIT et al. (2003) Valutare e certificare l'italiano di stranieri. I livelli iniziali. Perugia: Guerra.

COUNCIL OF EUROPE (2001) Common European Framework of Reference for Languages: Learning, teaching, assessment. Cambridge: Cambridge University Press.

CONSIGLIO D'EUROPA (2002 edizione italiana), Quadro comune europeo per le lingue: apprendimento, insegnamento, valutazione. Firenze in Milano: La Nuova Italia.

PORCELLI, Gianfranco (1998) Educazione linguistica e valutazione. Torino: UTET.

STAMBI, Beatrice (2004) Strumenti di verifica delle competenze linguistiche e comunicative degli apprendenti iniziali, L. Maddii (ur.), Insegnamento e apprendimento dell'italiano L2 in età adulta. Atene: Edilingua, 189-197.

STRAMBI, Beatrice in Anna Maria SCAGLIOSO (2004) Valutare e certificare l'italano L2, L. Maddii (ur.), Insegnamento e apprendimento dell'italiano L2 in età adulta. Atene: Edilingua, 62-188.

VEDOVELLI, Massimo (2002) L'italiano degli stranieri. Storia, attualità e prospettive. Roma: Carocci.

VEDOVELLI, Massimo (2002), Guida all'italiano per stranieri. Roma: Carocci.

\section{POVZETEK}

\section{Testiranje receptivnih in jezikovne zmožnosti $v$ italijanščini med študenti italijani- stike}

Čeprav študij Italijanskega jezika in književnosti na FF Univerze v Ljubljani v splošnem ne predvideva zgolj učenja modernega italijanskega jezika, saj je, kot že njegovo ime pove, zastavljen širše, bo prispevek prikazal nekaj glavnih izsledkov testiranja splošnega znanja italijanskega jezika, ki se je izvajal v vseh štirih letnikih: gre za izsledke na podro-

\footnotetext{
$15 \mathrm{~V}$ prvi in drugi letnik se pri lektorskih vajah doda nekaj več dejavnosti, kjer študenti razvijajo slušno razumevanje, $v$ razvijanje slušnega razumevanja pa se jih usmeri predvsem $\mathrm{v}$ okviru samostojnega učenja, kjer naj bi uporabljali ciljno pripravljena učna gradiva in krepili stik s sodobno italijanščino prek številnih medijev, ki jih imajo na razpolago. Poučevanje in učenje rabe glagola naj se spremeni tako, da bodo študenti po 1. in 2. letniku sposobni prepoznati temeljne rabe glagolskih oblik in jih ustrezno uporabiti. Usmeri se jih k samostojnemu učenju, kjer jim bodo na voljo ciljno pripravljena učna gradiva.
} 
čju bralnega in slušnega razumevanja ter uporabe slovničnih in leksikalnih struktur. Testiranje s testnimi kompleti CILS je potekalo kot del projekta, ki je nastal v okviru bilateralne pogodbe med italijanistikama v Ljubljani in Beogradu in se pričel izvajati konec študijskega leta 2009/2010 s prvim krogom testiranj (ostala dva sledita v naslednjih dveh letih). Prispevek se osredotoča na to, ali študenti dosegajo ustrezno raven znanja, ki smo jo v projektu predvideli oz. ocenili kot primerno za vsakega od štirih letnikov, in skuša odgovoriti na vprašanje, koliko študij prispeva k splošnemu znanju moderne italijanščine.

Ključne besede: študij italijanistike, italijanščina kot tuji jezik, testiranje, bralno in slušno razumevanje, znanje slovnice in besedišča

\section{ABSTRACT}

\section{Testing of both receptive and linguistic abilities in Italian among students of italian studies}

Although the study of Italian Language and Literature generally does not only consist of teaching/learning contemporary Italian as a foreign language (FL), the paper will present some of the main results of testing general proficiency in Italian as a FL achieved by most students from the first to the fourth years of Italian Studies at the University of Ljubljana. The presentation of results is limited to both receptive abilities (listening and reading comprehension) and to grammar and lexical proficiency. The testing project started with the first cycle of testing in May 2010 in the framework of a bilateral agreement between Italian Studies in Ljubljana and in Belgrade (the other two cycles will follow in 2011 and 2012). The paper is concerned about the (non) achievement of appropriate levels (1st to 4th year, from B1 to C2, respectively, according to the Common European Framework) agreed on by teaching staff at the two universities who considered their experience with students in the last years. It will attempt to sketch out some initial ideas about the extent to which the study of Italian Language and Literature contributes to general proficiency in Italian as a foreign language.

Keywords: Italian studies, Italian as a foreign language, testing, reading and listening comprehension, grammar and lexical abilities

\section{RIASSUNTO}

\section{Testing delle abilità ricettive e linguistica in italiano tra gli studenti d'italianistica}

Benché lo studio della lingua e della letteratura italiana generalmente non preveda il puro insegnamento della lingua moderna, il contributo passerà in rassegna alcuni dei risultati principali del testing sulla conoscenza generale della lingua italiana a cui gli studenti sono stati sottoposti: si tratterà dei risultati relativi all'ambito della comprensione orale/scritta e della competenza grammaticale e lessicale. Il progetto, nato all'interno di un accordo biennale bilaterale tra le sezioni d'italianistica delle Università di Ljubljana e di Belgrado, inizia alla fine dell'anno accademico 2009-2010 con lo svolgimento del primo ciclo di tre testing (altri due seguiranno nei due anni successivi). Il presente contributo si concentrerà sul raggiungimento o meno dei livelli prestabiliti, rispettivamente del primo, 
secondo, terzo e quarto anno di corso, e tenterà di dare una prima risposta alla domanda relativa al contributo fornito dallo studio alla conoscenza generale della lingua.

Parole chiave: studio dell'italianistica, italiano come lingua straniera, testing, comprensione scritta ed orale, conoscenze grammaticali e lessicali 